\title{
Russian Crime of the Past Decade: Is the Time of Illusions Over?
}

\author{
Dmitry V. Bakharev, Leonid I. Gamanenko, Mikhail L. Musharatsky and Andrey A. Ustinov
}

\author{
Perm Institute of the Federal Penal Service of Russia, Perm, Russia
}

\begin{abstract}
The purpose of the study is by analyzing the state and dynamics of crime in Russia over the past decade (2010-2020): 1) to identify the factors that influenced the criminal activity of the Russian population during this period; 2 ) determine the main directions of the then implemented state criminal policy; 3) assess its effectiveness. Research methods: method of summary and grouping of statistical observation materials, analysis of absolute and relative values (structure, intensity and dynamics), analysis of series of dynamics. The results of the study indicate that, since 2015, there has been a progressive increase in crime in Russia, due to unfavorable trends in the development of the socioeconomic sphere. During this period, there was also a significant discrepancy between the data of official crime statistics and the real situation in the field of crime. This discrepancy was due to large-scale transformation processes taking place in the sphere of the state's criminal policy. Accordingly, the decrease in the amount and level of official crime in Russia in 2016-2018 was a consequence of these processes, while the real crime continued to grow all these three years. However, the sharp increase in crimes against property committed through the use of information and communication technologies, which began in Russia several years ago, ultimately could not but be reflected in the data of official crime statistics - in the past two years, an increase in both the amount and the level of crime has been recorded in the state. Russian law enforcement agencies have so far shown their unwillingness to offer serious resistance to digital crime. Russian law enforcement agencies have so far demonstrated their unwillingness to offer serious resistance to digital crime. The situation is significantly complicated by the fact that a significant part of crimes in the sphere of information and communication technologies is committed by inmates of Russian prisons. This means that today, in addition to a strong external influence from the criminal environment, the country's law enforcement system is also experiencing a powerful endogenous influence from the criminals who are already serving their sentences in prisons.
\end{abstract}

Keywords: Criminality, Russia, official crime statistics, criminal policy, ICT crime.

\section{INTRODUCTION}

Analysis of the status and dynamics of crime in Russia over the past decade (2010-2020) is of considerable research interest in terms of 1 ) identifying the factors influencing the criminal activity of the population, and 2) assessing the effectiveness of the implemented state criminal policy in Russia. The fact is that during this period: a) the crime trend has repeatedly changed; b) criminal legislation, as well as the system of law enforcement agencies, have undergone a significant transformation; c) finally, the general socio-economic situation in the country has changed radically the period of growth in the well-being of the population of Russia (2010-2013) was replaced by a steady downward trend in the standard of living of the overwhelming majority of residents (2014-2020).

At first glance, the data of the official crime statistics of the Russian Federation for 2010-2020 show the presence of a positive trend in the development of the crime situation during this period. Thus, the total number of crimes registered during this period has decreased by almost a quarter, and the crime rate (the number of registered crimes per 100 thousand people) in the state has also decreased in a similar proportion. It should be especially emphasized that the number of

*Address correspondence to these authors at the Department of Public Law Perm Institute of the Federal Penal Service of Russia, Perm, 614012, Russia; E-mail: demetr79@mail.ru registered serious and particularly serious offences has decreased by $17 \%$. At the same time, the number of thefts - the most widespread crimes in Russia during the entire post-Soviet stage of the country's development - has decreased by almost a third. The number of registered crimes in the sphere of illegal drug trafficking has decreased by about $15 \%$, and the number of the most dangerous crimes against property - plunders and robberies - has decreased by more than four times (See Table 1. Hereinafter, unless otherwise stated, all statistics are given in accordance with: Brief Description of the State of Crime in the Russian Federation 2010-2020).

Such a favourable situation in crime contributed to positive shifts in the sphere of criminal procedure of the state's activities. In particular, the caseloads of the courts have decreased: the number of criminal cases brought to court has decreased by more than a quarter; the number of convicts has decreased by almost $45 \%$. The number of petitions for the selection of a preventive measure in the form of detention in custody has also decreased by $42 \%$ (See Table 2 . The data are given according to Judicial Department at the Supreme Court of the Russian Federation. Judicial Statistics on Cases considered by Federal Arbitration Courts, Federal Courts of General Jurisdiction and Justices of the Peace. 2010-2020).

Ultimately, all this could not but have a favourable effect on the workload of the institutions of the 
Table 1: State and Dynamics of Crime in the Russian Federation (2010-2020)

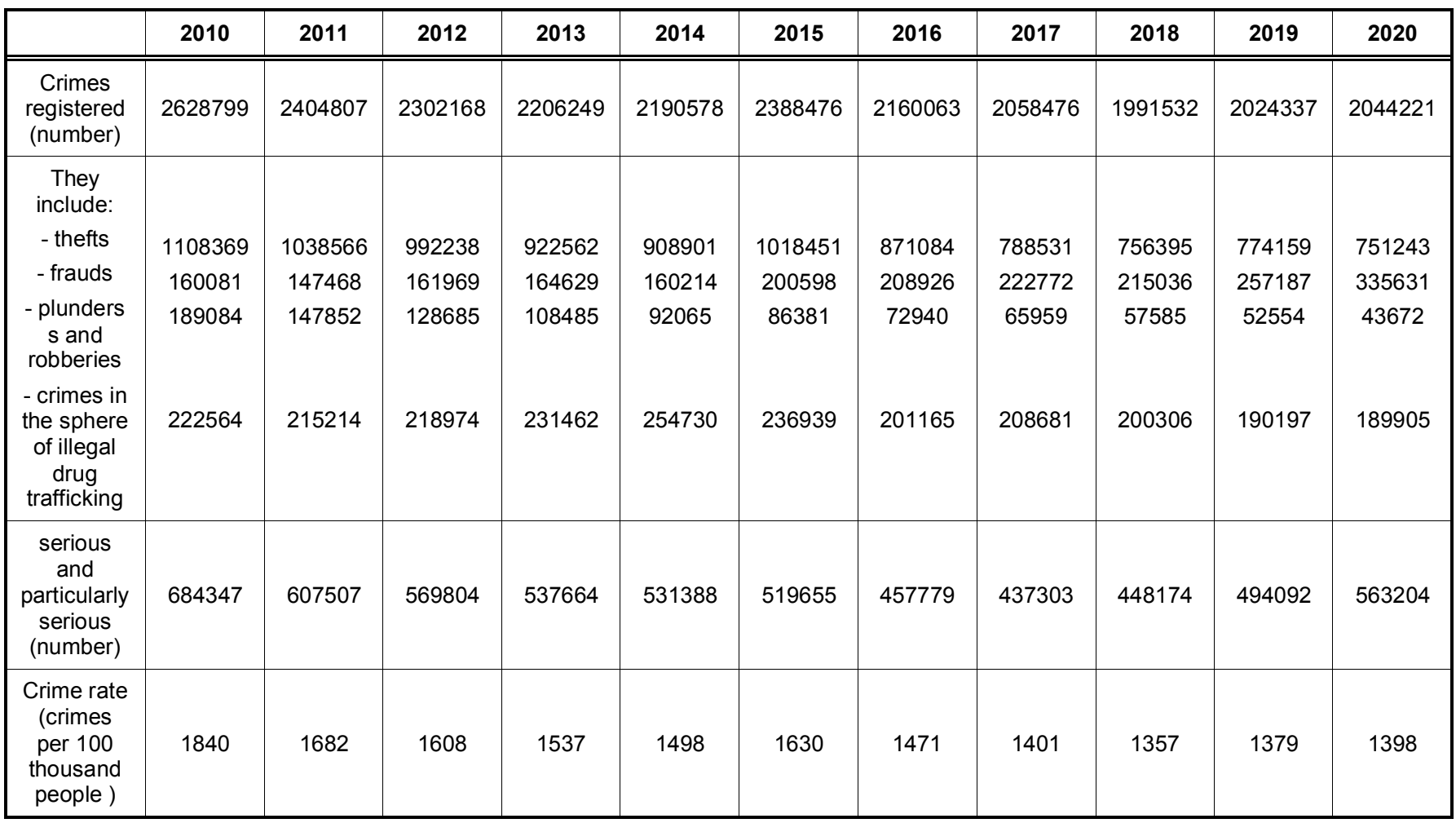

Table 2: Information on the Activities of the Courts in Criminal Cases (2010-2020)

\begin{tabular}{|c|c|c|c|c|c|c|c|c|c|c|c|}
\hline & 2010 & 2011 & 2012 & 2013 & 2014 & 2015 & 2016 & 2017 & 2018 & 2019 & $\begin{array}{c}2020 \\
\text { (first } \\
\text { half of } \\
\text { the } \\
\text { year) }\end{array}$ \\
\hline $\begin{array}{l}\text { Received } \\
\text { criminal } \\
\text { cases } \\
\text { (number) }\end{array}$ & 1064538 & 989231 & 947647 & 946474 & 936771 & 966416 & 954255 & 915781 & 883993 & 820414 & 391226 \\
\hline $\begin{array}{c}\text { Convicted } \\
\text { persons }\end{array}$ & 845071 & 782274 & 739278 & 735590 & 719305 & 733607 & 741329 & 697054 & 658291 & 598214 & 234227 \\
\hline $\begin{array}{c}\text { Considered } \\
\text { petitions for } \\
\text { the selection } \\
\text { of a } \\
\text { preventive } \\
\text { measure in } \\
\text { the form of } \\
\text { detention in } \\
\text { custody } \\
\text { (number) }\end{array}$ & 165323 & 152028 & 147784 & 146993 & 147428 & 154066 & 136244 & 126100 & 113141 & 104866 & 47714 \\
\hline
\end{tabular}

penitentiary system in Russia. Thus, the number of persons, contained therein, for the period also significantly reduced $(-41 \%)$, while the number of persons contained in the colonies for adults, reduced by $46 \%$ and those contained in pre-trial detention centres by $12 \%$ (See Table 3 . The data are given according to Federal Penitentiary Service of Russia. Statistical data. 2010-2020). So, at first glance, the 
Table 3: The Number of Persons Held in the Institutions of the Federal Penal Service of Russia (2010-2020)

\begin{tabular}{|c|c|c|c|c|c|c|c|c|c|c|c|}
\hline & 2010 & 2011 & 2012 & 2013 & 2014 & 2015 & 2016 & 2017 & 2018 & 2019 & 2020 \\
\hline $\begin{array}{l}\text { Number of persons } \\
\text { held in: } \\
\text { - colonies for adults }\end{array}$ & 694638 & 639548 & 585020 & 559841 & 551118 & 525056 & 519601 & 495139 & 461006 & 423825 & 376128 \\
\hline $\begin{array}{l}\text { - pre-trial detention } \\
\text { centres }\end{array}$ & 119363 & 112382 & 113824 & 114294 & 117700 & 118026 & 107568 & 104563 & 99945 & 99003 & 104413 \\
\hline Total: & 814001 & 751930 & 698844 & 674135 & 668818 & 643082 & 627169 & 599702 & 560951 & 522828 & 480541 \\
\hline
\end{tabular}

criminal situation in Russia in the past decade looked quite stable, with a general trend towards a decrease in the amount and level of crime, as well as a change in the structure of crime towards a decrease in the proportion of serious and particularly serious offences.

Based on these data, we will try to: 1) identify the factors that influenced the criminal activity of the population of Russia during this period; 2) determine the main directions of the then implemented state criminal policy; 3 ) assess its effectiveness.

\section{METHODS}

To achieve this goal, we applied a comprehensive statistical analysis, which includes: 1) the method of summarizing and grouping materials of statistical observation of crimes in the sphere of drug trafficking, beatings, as well as the number of convicts held in Russian colonies for adults; 2) analysis of these absolute and relative values; 3 ) analysis of the series of their dynamics.

\section{RESULTS AND DISCUSSION}

In our opinion, these positive changes represent the situation which is commonly called the "visible part of the iceberg". One of the authors of this article a couple of years ago already suggested that the real picture of modern Russian crime was distorted in official crime statistics. The idea was substantiated that the real crime rate, starting from 2015, did not decrease, but, on the contrary, had a stable tendency to increase. (Bakharev, 2019). In 2019, this assumption was also confirmed by the facts: during this year the increase in the crime rate in relation to the previous one was about $1.6 \%$. This year this figure has increased by another $1 \%$. The numbers are small, but they seem to indicate a real trend towards a worsening crime situation.

In 2015, we wrote: "The increase in the crime rate, which is already observed in a number of regions of the Russian Federation, in the next two or three years will become a ubiquitous picture" (Bakharev, 2015b: 147), and, we repeat, in our opinion, this trend is indeed taking place. We repeat that in our opinion, this trend takes place starting from 2015. The fact is that crime in Russia, as in any country with a low level of economic development and its unstable state, is very closely correlated with the level and dynamics of the socioeconomic situation of the population. Crime statistics show this very clearly (Bakharev, 2011; Bakharev, 2015a). In fact, starting from 1991 (when data on the state and level of crime were declassified) and up to recent years, in the history of the country, there was only one period of a clear decline in crime rates, namely, 2007-2013. The same period was the only time period in the entire post-Soviet stage of the country's development when there was active growth of the Russian economy and, as a result, there was a significant improvement in the well-being of Russian citizens. Accordingly, in this logical chain, it is not surprising that the crime rate jump in 2015 (by 8.8\%) coincided with the moment when signs of an economic crisis appeared in the country (Bakharev, 2016: 466471). On the contrary, it is surprising: a) the fact of a very rapid adaptation of the Russian population as early as in 2016 to the consequences of this crisis, a sign of which was the decline in the official crime rate by $10 \%$; and $b$ ) the subsequent decrease in the crime rate in 2017-2018 against the backdrop of the continuing deterioration in the welfare of the overwhelming share of the country's population. It seems that this was the result that the state achieved through the implementation of, if not direct, but indirect measures in the sphere of criminal policy. Indirect because the goals of their implementation, most likely, were not only (and sometimes not so much) of a criminal policy nature, but ultimately they still had a significant impact on the sphere of the social control over crime.

Thus, in April 2016, the Federal Drug Control Service (FDCS) was liquidated. Its long-term "competition" with a division of the Ministry of Internal 
Affairs (the General Directorate for the Control of Drug Trafficking), performing similar tasks (Alieva and Surkhaeva, 2018), led to the fact that in 2014 the country recorded a record number (since the beginning of this century) of detected crimes in the sphere of illegal drug trafficking - 254.730 (2015 - 236.939). Their share in the structure of registered crime was $11.6 \%(10 \%)$. However, as early as 2016 , the number of registered crimes in this category decreased by $15 \%$, and their share in the total amount of crime decreased to $9.3 \%$.

A similar trend continues to this day: the number of registered crimes in the sphere of illicit drug trafficking is decreasing annually (even within a context of an increased amount of crime in 2019-2020), as well as its share in the total volume of crime $(2020-9.3 \%)$.
Furthermore, in February 2017, there was decriminalization of such corpus delicti as "causing physical injuries to family members for the first time". This measure received a very negative assessment in the doctrine of Russian criminal law. (Grishchenko and Serogodskaya, 2020; Kapkova, 2019; Mikhailyuk, 2020; Nigmetova, Leonova and Lopashenko, 2020; Voroshilova and Muzykankina, 2019; Yakovlev, E. 2019). Such policy in the crime field quickly led to a reduction in the number of all reported beatings. These changes were not slow to affect the statistics of reported beatings in general. Thus, if in 201681.646 beatings were registered, and in January 2017 (i.e. on the eve of decriminalization) -9.317 of such crimes, then for the whole of 2018 only 7.859 beatings were registered. That is, the total number of such crimes has decreased by more than 10 times in one year. In the

Table 4: The Situation and Development on the Conviction for Crimes Related to Drug Trafficking (2010-2020)

\begin{tabular}{|c|c|c|c|c|c|c|c|c|c|c|c|}
\hline & 2010 & 2011 & 2012 & 2013 & 2014 & 2015 & 2016 & 2017 & 2018 & 2019 & $\begin{array}{c}2020 \text { (first } \\
\text { half of the } \\
\text { year) }\end{array}$ \\
\hline $\begin{array}{l}\text { Total number of } \\
\text { convicted in the } \\
\text { sphere of illegal } \\
\text { drug trafficking } \\
\text { (persons) }\end{array}$ & 105095 & 109942 & 106393 & 109167 & 114471 & 114543 & 109414 & 107839 & 95785 & 78284 & 30967 \\
\hline $\begin{array}{l}\text { - of them } \\
\text { incarcerated }\end{array}$ & 51392 & 46426 & 44068 & 43611 & 46204 & 48867 & 44450 & 42135 & 37818 & 31345 & 11146 \\
\hline $\begin{array}{c}\text { Convicted under } \\
\text { Part } 1 \text { of Article } \\
228 \text { of the } \\
\text { Criminal Code } \\
\text { of the Russian } \\
\text { Federation (drug } \\
\text { users) }\end{array}$ & 43816 & 41982 & 42573 & 45171 & 43057 & 43589 & 42015 & 44582 & 39160 & 34273 & 14154 \\
\hline $\begin{array}{l}\text { - of them } \\
\text { incarcerated }\end{array}$ & 12455 & 10206 & 8669 & 8932 & 8168 & 7807 & 7247 & 7359 & 6380 & 5178 & 1895 \\
\hline $\begin{array}{l}\text { Convicted under } \\
\text { Part } 1 \text { of Article } \\
228 \text { of the } \\
\text { Criminal Code } \\
\text { of the Russian } \\
\text { Federation (drug } \\
\text { users) (serious } \\
\text { offence) }\end{array}$ & 26116 & 28744 & 34720 & 35836 & 44944 & 45031 & 37609 & 35144 & 30212 & 24626 & 10023 \\
\hline $\begin{array}{l}\text { - of them } \\
\text { incarcerated }\end{array}$ & 11693 & 12425 & 14676 & 14217 & 17759 & 19535 & 16256 & 15368 & 12584 & 9628 & 3462 \\
\hline $\begin{array}{l}\text { Convicted under } \\
\text { Part } 1 \text { of Article } \\
228 \text { of the } \\
\text { Criminal Code } \\
\text { of the Russian } \\
\text { Federation } \\
\text { ("dealers") } \\
\text { (serious and } \\
\text { particularly } \\
\text { serious } \\
\text { offences) }\end{array}$ & 28790 & 25674 & 21957 & 21208 & 20715 & 21829 & 21265 & 19709 & 18836 & 17044 & 6010 \\
\hline
\end{tabular}


past two years, there has also been a clear downward trend in the number of reported beatings: $2019-6.914$, $2020-5.716$.

Another point that deserves attention - is the structure of crime in illicit drug trafficking. If in 2010 , in the total number of all those convicted of these crimes, the share of those convicted of the acquisition and possession of narcotic drugs in substantial amounts and on a large scale ("drug users") was $66.5 \%$, then in 2020 it increased to $78 \%$, while the share of convicted "dealers", on the contrary, decreased from $27.4 \%$ to $19.4 \%$ during this period (See Table 4 the data are given according to: Judicial Department at the Supreme Court of the Russian Federation. Judicial Statistics on Cases considered by Federal Arbitration Courts, Federal Courts of General Jurisdiction and Justices of the Peace. 2010-2020).

Thus, the fight against drug-related crime in Russia is becoming more and more extensive: the main burden of criminal repression is borne by "ordinary" drug users, while the probability of being prosecuted for drug traffickers decreases every year. In addition, in 2012 the Russian Criminal Code forged additional restraints for persons sentenced to imprisonment for serious and particularly serious offences in the sphere of illegal drug trafficking: they are eligible for parole after at least three-quarters of the sentence.

It should be reminded that in 2019, this category included $83.5 \%$ of the total number of people sentenced to imprisonment for crimes in the sphere of drug trafficking, and in $2020-87 \%$ (See Table 4). With a considerable degree of confidence, it can be assumed that this circumstance contributed to the fact that the share of convicts held in colonies for crimes related to drug trafficking, since 2011, exceeds the number of convicts for all other most common categories of crimes (See Table $\mathbf{5}$. The data are given according to: Federal Penitentiary Service of Russia. Statistical data. 2010-2020). Moreover, in 2020, the number of persons imprisoned for committing crimes in the sphere of illegal drug trafficking was $17.5 \%$ higher than the total number of convicts imprisoned for committing thefts, robberies, and plunders. This fact leads us to one more thought.

As is known, vested encroachments on private property, which dominate the structure of modern property crime and, accordingly, crime in Russia as a whole, are largely determined by the alcohol and drug addiction of the perpetrators (Shiyan, 2016). Accordingly, imposing criminal liability on a person for committing drug-related crimes and incarcerating him actually serves as a preventive measure against the subsequent commission of property crimes by this person. Therefore, it can be assumed that a slight increase in thefts in the "crisis" the year of 2015, as well as a subsequent decrease in their amount in 20162020 , was largely the result of isolation in penitentiary institutions of a potentially criminal (in terms of acquisitive crimes) population.

Thus, the decline in the amount and level of official crime in Russia in 2016-2018, in our opinion, is a consequence of the processes described above that took place in the sphere of the criminal policy of the Russian state. At the same time, real crime, we are sure, continued to grow all these three years. What happened next? Why official statistics, since 2019, cannot but capture the tendency for growth and crime in the country?

The answer to this question, we believe, is quite simple - in Russia, there is an explosive growth of

Table 5: Number and Structure of Convicts Held in Adult Colonies (2010-2020)

\begin{tabular}{|c|c|c|c|c|c|c|c|c|c|c|c|}
\hline & 2010 & 2011 & 2012 & 2013 & 2014 & 2015 & 2016 & 2017 & 2018 & 2019 & 2020 \\
\hline $\begin{array}{l}\text { Number of persons } \\
\text { held in adult } \\
\text { colonies }\end{array}$ & 694638 & 639548 & 585020 & 559841 & 551118 & 525056 & 519601 & 495139 & 461006 & 423825 & 376128 \\
\hline $\begin{array}{c}\text { Of them convicted } \\
\text { of: } \\
\text { - theft }\end{array}$ & 131576 & 114984 & 97356 & 91816 & 88145 & 75245 & 76693 & 73493 & 68906 & 62261 & 52612 \\
\hline - robberies & 61693 & 53472 & 45066 & 40895 & 37589 & 33133 & 31034 & 27382 & 23465 & 20159 & 16307 \\
\hline - plunders & 69619 & 62266 & 55063 & 49697 & 45827 & 41619 & 38093 & 34346 & 29589 & 25233 & 20963 \\
\hline $\begin{array}{l}\text { - crimes in the } \\
\text { sphere of illegal } \\
\text { drug trafficking }\end{array}$ & 124408 & 125141 & 124955 & 123185 & 127161 & 134245 & 138260 & 136029 & 130143 & 120100 & 108943 \\
\hline
\end{tabular}


property crimes in the sphere of information and communication technologies. In the vast majority of cases, they are committed in the form of fraud. In general, the dynamics of all registered crimes of this type, starting from 2012 (except for 2014 and 2018), showed an upward trend: the total number of recorded crimes of this type has more than doubled. The share of fraud in the total number of property crimes has also doubled (from $14.2 \%$ in 2010 to $29.7 \%$ in 2020). The ratio of thefts and frauds changed in an even greater proportion: if in 2010 there were almost seven thefts for one fraud, in 2018 there were only two. As for crimes committed with the help of information and communication technologies, in 2019 their official growth was $68.5 \%$ (despite the fact that in the statistical reporting of the Ministry of Internal Affairs, these crimes are singled out in a separate category only from the second half of 2019), and in 2020 $73.4 \%$. The share of fraud among them is $41 \%$; theft is $34 \%$ (2020). In 2020, there was literally an outbreak of such crimes committed using payment (plastic) cards $(+453 \%)$. At the same time, the share of only this type of crime in the total amount of registered crime was $9.3 \%$, and the total share of crimes committed in the sphere of information and communication technologies in 2020 amounted to almost $25 \%$. To date, it is the most widespread type of crime in Russia. Apparently, the law enforcement system does not yet have adequate means of countering it. This is indicated by the extremely low figures for the detection of such crimes: $2019-22 \%, 2020-18.6 \%$.

It should also be mentioned that the data of criminological science indicate that a significant proportion of such crimes is committed by persons who are already serving a sentence in penitentiary institutions in Russia. (Santashov, 2021; Sautina and Kuznetsova, 2019; Ustinov and Titanov, 2016) and "experiencing drug use problems" (Tretyakov, 2021). Thus, criminal punishment, in this case, ceases to fulfil its main function - preventive. Figuratively speaking, the "hand" of Russian crime "reaches up" to the citizens even over the high prison wall at present.

\section{CONCLUSION}

The above facts and the results of their analysis allow us to formulate a number of theses regarding the essence of the problem under consideration:

1. Unfavourable trends in the development of the socio-economic sphere in Russia have led to a progressive increase in crime in the country since 2015, which continues to the present.
2. The transformation processes taking place in the sphere of criminal policy had a softening, smoothing effect on the official crime indicators, as a result of which in 2016-2018 they did not reflect the real trends in the development of the crime situation in the country.

3. The sharp increase in the number of crimes against property committed through the use of information and communication technologies, which began in Russia several years ago, ultimately could not but be reflected in the data of official crime statistics - in the last two years, an increase in the amount and the level of crime, in general, has been recorded in the country.

4. Russian law enforcement agencies have so far demonstrated their unwillingness to offer serious resistance to digital crime. The situation is significantly complicated by the fact that a significant part of crimes in the sphere of information and communication technologies is committed by inmates of Russian prisons. This means that today, in addition to a strong external influence from the criminal environment, the country's law enforcement system is also experiencing a powerful endogenous influence from the criminals who are already serving their sentences in prisons.

Thus, we believe that if the Russian state plans to change the current crime situation in a more favourable direction, then it is time for it to part with the illusions of "stability" and take into account all the above circumstances when developing a strategy for organizing social control over crime in the current decade.

\section{REFERENCES}

Alieva, E., Surkhaeva, Kh. 2018. Administrative Reform of the Ministry of Internal Affairs in the Field of Drug Control: Prerequisites and Results. Eurasian Law Journal 6: 156-158.

Bakharev, D. 2019. On the Illusions and Realities of the Russian Criminal Policy of the Last Decade. Bulletin of the Perm Institute of the Federal Penitentiary Service of Russia 4: 914.

Bakharev, D. 2016. Spatial Analysis of the Causal Complex of Crime. St. Petersburg: Publishing House "Juridical Center".

Bakharev, D. 2015a. The Causes and Regularities of Crimes on the Territories of the Central Federal District: The Theoretical Background, Methodology and Results of Spatial Analysis. Journal of Baikal National University of Economics and Law 9 (3): 33-41. https://doi.org/10.17150/1996-7756.2015.9(3).608-623

Bakharev, D. 2015b. The "Time of Leviathan», or Why are Russia's Regions Facing the Crime Rate Growth Again. Forensic Library 6:138-148. 
Bakharev, D. 2011. The Use of Integral Indexes in Studying Social and Economic Factors of Territorial Differentiation of the Crime Level: History and Modern Prospects. Criminology Journal of Baikal National University of Economics and Law 1: $608-623$.

Brief Description of the State of Crime in the Russian Federation 2010-2020 [Electronic document]. Statistics from the Ministry of Internal Affairs of the Russian Federation. https://xn-b1aew.xn--p1ai/folder/101762.

Federal Penitentiary Service of Russia. Statistical data. 2010-2020. [Electronic document]. https://fsin.gov.ru/statistics/.

Grishchenko, V., Serogodskaya, E. 2020. An Assessment of the Decriminalization of Beating. Legal Fact 100: 24-26.

Judicial Department at the Supreme Court of the Russian Federation. Judicial Statistics on Cases considered by Federal Arbitration Courts, Federal Courts of General Jurisdiction and Justices of the Peace. 2010-2020. [Electronic document]. http://cdep.ru/index.php?id=5.

Kapkova, M. 2019. Beatings Against Loved Ones. Actual Problems of Administrative Law and Process 1: 25-27.

Mikhailyuk, A. 2020. Problems of Differentiation of Criminal Liability for Beatings and Torture, and Ways to Solve Them. Modern scientist 3: 289-293.

Nigmetova, V., Leonova, A, Lopashenko, N. 2020. Some problems of the criminal law regulation of beatings. Norwegian Journal of development of the International Science 40-3: 35-37.
Santashov, A. 2021. Economic Crimes, committed in Places of Deprivation of Liberty Remotely. Countering Cybercrimes and Crimes in the Field of High Technologies. Materials of the All-Russian Scientific and Practical Conference (Moscow, December 10, 2020). Moscow: Moscow Academy of the Investigative Committee of the Russian Federation.

Sautina, S., Kuznetsova, O. 2019. The use of Information and Telecommunication Technologies when committing Crimes in Places of Deprivation of Liberty // Transformation of State and Law in the Context of Global Digitalization of Society. Materials of the All-Russian Scientific and Practical Conference. Irkutsk: ISU Publishing House.

Shiyan, V. 2016. Socio-Demographic and Pathopsychological Characteristics of Participants in Illegal Drug Trafficking. Drug Control 4: 3-8.

Tretyakov, I. 2021. Drug Addicted Criminals (An Attempt at Criminological Analysis). Drug Control 1: 23-27.

Ustinov, A., Titanov, M. 2016. Criminological Characteristic's of Crime in Prisons. Gaps in Russian Legislation 2: 146-150.

Voroshilova, S., Muzykankina, Yu. 2019. Decriminalizing Battering: Old Traditions and Modern Realities. Bulletin of the Saratov State Law Academy 4: 15-22.

Yakovlev, E. 2019. Some Results of Decriminalization of Beating. Actual Problems of Combating Crimes and Other Offenses 1: 102-103.

Received on 24-03-2021

https://doi.org/10.6000/1929-4409.2021.10.129

(c) 2021 Bakharev et al.; Licensee Lifescience Global.

This is an open access article licensed under the terms of the Creative Commons Attribution Non-Commercial License (http://creativecommons.org/licenses/by-nc/3.0/) which permits unrestricted, non-commercial use, distribution and reproduction in any medium, provided the work is properly cited. 